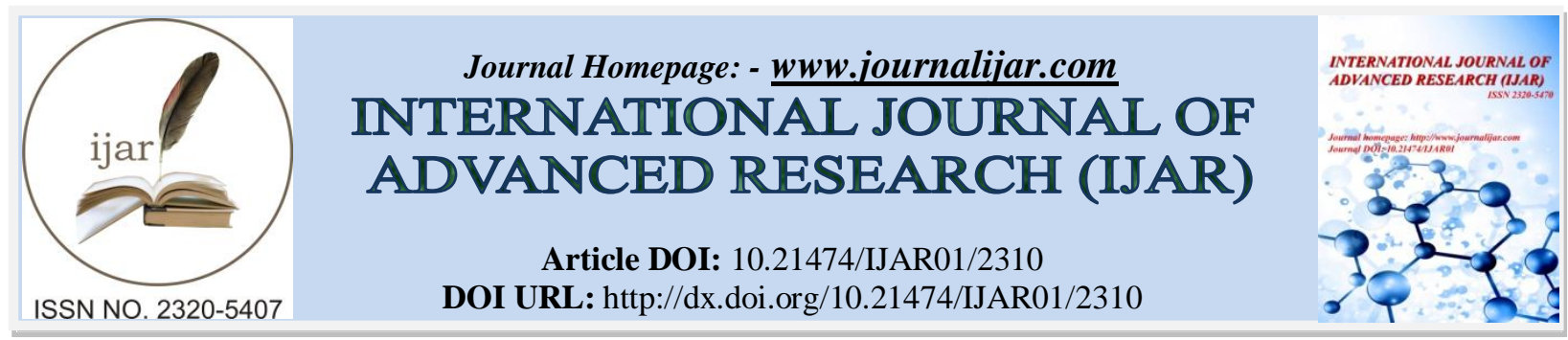

RESEARCH ARTICLE

\title{
BIO-ECOLOGY OF H.HAMPEI IN COFFEE PLANTATION IN SUMBUL AND SIDIKALANG DISTRICTS, NORTHERN OF SUMATERA, INDONESIA.
}

Ameilia Zuliyanti Siregar.

Lecture in Agroecotechnology at Agricultural Faculty, University Sumatera Utara, Indonesia 20155.

\section{Manuscript Info}

Manuscript History

Received: 29 September 2016

Final Accepted: 30 October 2016

Published: November 2016

Key words:-

Biochemical, identification, dichloro diphenyl trichloroethane, bacteria, polluted soil

\section{Abstract}

Coffee berry borer (Hypothenemus hampei Ferr.) can be controlled using attractant trap which comes from the leaves and bark of coffee beans. The purpose of this study was to determine Bio-ecology of coffee berry borer (CBB), Hypothetamus hampei and ability to extract and rind of coffee as an attractant for imago fruit borer coffee with different levels of concentration. This research was conducted in the district and sub-district Sumbul and Sidikalang from August 2016 to October 2016. The results showed Bio-ecology of H. hampei pests that can be observed from the development of the egg, pupa and imago of H.hampei in Sidikalang and Sumbul, Dairi. Attractant trap of chlorogenic acid from leaves and bark of the coffee fruit is most effective in controlling the pest $\mathrm{CBB}$ in the field of ten repetitions recorded from 7 replicates very significant, consisting of the S3, S4, S6, S7, S8, S9 and S10 ( $\mathrm{p}<0: 00-0.02)$ in Sumbul and Sidikalang. Developments of $H$. hampei affected by temperature and the availability of the coffee fruit. Factors influencing the development of $H$. hampei namely; continuous supply of fruit from generation to generation; the shade is too dense resulting in high humidity; and fulfilled the host plant consisting of Tephrosia sp, Centrosoma sp, Oxicanthus sp. The use of attractants chlorogenic acid leaves and rind of coffee pest control of CBB (H.hampei) is one effort in keeping the coffee commodity Dairi, North Sumatra.

Copy Right, IJAR, 2016,. All rights reserved.

\section{Introduction:-}

Since the 1980s, the coffee export is third commodity in Indonesia reached 300,000 to 350,000 ton per year, after the wood and rubber. Increasing export demand should be offset by an increase in quality improvement. This is necessary because in 1982 the FDA (Food and Drug Administration) United States 600 tons of coffee are refuse because they contain pests and diseases so that further development of Indonesia's coffee exports increasingly determined by quality aspects. Why is there are pests which become contaminants in coffee exports? From observations and tests performed, experts and practitioners support the Indonesian coffee contains several contaminants, namely insects, fungi and pests. Insects contaminants can be carried from the field at harvest and during storage in a warehouse. There are two types of pests that attack coffee and can threaten the quality of coffee exports Indonesia, namely: Hypothenemus hampei (coffee berry borer) and Planococcus citri and C.viridis. $H$. hampeii is a major pest of coffee that can be attacked since in the field until the on-site storage. Female beetles bore holes in the disc (the end) of coffee that are still green to lay their eggs. The larvae that hatch that will uplift 
and damage fruit and coffee beans so the coffee into crumbs or crushed and worthless. In addition, when the field and in the warehouse, H. hampei will survive on coffee beans, especially among farmers who store coffee beans in the absence of drying or drying treatment at all or drying is less than perfect. It was therefore considered necessary and important to know bioecology H.hampei in controlling the major pest of coffee in Dairi, particularly in North of Sumatra, Indonesia.

\section{Research Methods:- \\ Place and Time:}

The research was conducted in coffee plantations plantation communities in Sumbul and Sidikalang Districts, Dairi. Followed by chemical analysis at the Laboratory of Chemistry USU and identification of pests in the Laboratory of Plant Pests and Diseases Faculty of Agriculture, North Sumatera University from July 2016 to September 2016.

\section{Materials and Tools:-}

Materials:-

The materials used in this study are the leaves and coffee beans of $1 \mathrm{~kg}$ each ingredient of varieties of arabica and robusta, arabica coffee plants and robusta, a solution of the compound chlorogenic acid, distilled water, adhesive strips, Whatman filter paper No. 1, gauze, black cloth, plastic bags, detergent, data books and stationery, plastic paper, labels, and other materials that can support the research.

\section{Tools:-}

The tools used in this study were scales, mortal, erlenmeyer, jars plastic, cabinet dryer, blender, bottle tubes, plastic bottles, refrigerator temperature of $40 \mathrm{C}$, rotavapour temperature is $400 \mathrm{C}$, measuring cups, cutter, plastic containers, glass magnifying, pin, rope, camera, washbasin, cool box, wire, and tools supporting more research.

\section{Implementation Research in the Field:-}

The study randomized complete block design (RCBD) non factorial with 5 the best treatment of the observations in the laboratory with five groups so that there are 25 experimental units:

K0: Control (Aquadest)

K1: chlorogenic acid Extract I (plus water $25 \mathrm{ml}$ )

$\mathrm{K} 2$ : chlorogenic acid Extract II (water plus $50 \mathrm{ml}$ )

K3: Extracts of chlorogenic acid III (water plus $75 \mathrm{ml}$ )

K4: Extracts of chlorogenic acid IV (plus water $100 \mathrm{ml}$ )

Each experimental unit consisted of four coffee planting locations with each location taken at random 5 by 5 treatment plants so that the plants experiment as much $4 \times 5 \times 5=100$ plants. Data were analyzed using analysis of variance model of linear randomized block design using SPSS version 24.00.

\section{Results And Discussion: \\ Description Bioecology of H.hampei in Coffee Plantation in Dairi:-}

According Feny and Endang (2016), H.hampei known by the local name coffee berry borer (CBB) has the proportion of most attacks (33\%), followed by P.citri (13\%), C.viridis (12\%) and other plant pest organisms on coffee planting (Sector Protection, 2014; BBPPT Surabaya, 2014). Bio-eckology of CBB, H.hampei (Coleoptera) categorized into imago is black-brown, female body length of about $2 \mathrm{~mm}$, and males about $1.3 \mathrm{~mm}$. Eggs are laid in coffee seeds begin to harden at a temperature of $27^{\circ} \mathrm{C}$. Old egg stage ranges from 5-9 days, long larval stage is 1026 days with pre pupa two days and the pupal stage about 4-9 days. The period of development from egg to adult for 25-35 days. Old female insects live an average of 156 days and a maximum of 103 male insects a day (Sartika, 2012). Factors affecting the development of CBB, H.hampei are: continuous supply of fruit from generation to generation; shade is too dense resulting in high humidity; and fulfilled the host plant consisting of Tephrosia sp,

\section{Centrosoma sp, Oxicanthus sp:-}

H. hampei development is affected by temperature and the availability of the coffee fruit. H. hampei can live at $35^{\circ} \mathrm{C}$ $15^{\circ} \mathrm{C}$ - temperature, the optimum temperature for growth between $30^{\circ} \mathrm{C}-32^{\circ} \mathrm{C}$ eggs and larva, pupa and adult between $27^{\circ} \mathrm{C}-30^{\circ} \mathrm{C}$. Female insects can menggerek cherries between temperature $20^{\circ} \mathrm{C}-33^{\circ} \mathrm{C}$, at a temperature of $15^{\circ} \mathrm{C}$ and $35^{\circ} \mathrm{C}$ female insects failed menggerek coffee cherries or coffee berries were able menggerek but do not lay eggs (Jaramilo et al., 2009). Effective control of H. hampei is currently located in an area, namely the land sanitation 
by spoils (picking whole fruit on the tree after the harvest), reduce soil moisture by the pruning of the coffee plants and shade plants. Breaking the life cycle, covering the action picking fruit, which started the harvest by picking all the ripe fruit was attacked by $H$. hampei and not 15-30 days before the harvest is great. Lelesan namely collecting all the coffee fruit that fell on good soil to fruit or fruit attacked not attacked. Racutan or spoils are picking all the fruit on the tree at the end of the harvest. All material results quotation powder, lelesan and racutan soaked in hot water for about 5 minutes. Before getting into the storehouse, preferably coffee beans in the sun or dried to perfection to avoid $H$. hampei up into the warehouse. Biological control can be done by utilizing some natural enemies $H$. hampei which has been continuously developed is the fungus Beauveria bassiana as insect pathogens, predators such as spiders, wasps paper, cecopet, mantises, beetles dome, tiger beetles, ground beetles, dragonfly and several kinds of ladybugs and parasitoid Stephanoderis cephalonomia and Prorops nasuta (Bethylids), Phymastichus coffea (Eulophid), and Coffeicola heterospilus braconid all come from Africa.

\section{H.Hampei Attack Symptoms Were Observed In Coffee Plantation In Dairi:-}

Research in the field indicates CBB began gnawing green coffee cherries are the factors that determine the success rate of the pests in broaching, especially during the dry matter content of more than 20\% (Murphy and Moore, 1990; Vega et al, 2009). Further preference CBB attacked coffee plants in red or black fewer, so it is not possible produktivitaskopi increase. Assumed when the coffee reaches the color cooking, coffee has been attacked by in sects H.hampei. Then the coffee quality requirements (such as seed size, moisture content, and the percentage of disability) was good and consumer demands for hygiene and health requirements so that coffee exports will be limited if it is attacked by pests of CBB, H.hampei. Color black beans, black majority, the black rupture, perforated one seed, and the seed cavities more than one caused by pests and diseases is the value of defect (defect system) that must be corrected in coffee exports (Ceylon, 2012).

Figure 1 shows the attack of CBB, H. hampei in Sub Sumbul and Sidikalang District. First, the adult female of CBB create a hole, then into the endosperm. Attacks on young fruits only for the purpose of food for imago which can cause fruit fall and rot where they lay eggs; after hatching, the larvae inside the beans will reduce the yield and quality of coffee valuable products. Insects spent most of his life in coffee beans, so it is very difficult to control. Red coffee fruit is a fruit that is favored by female insects to breed supported by a study conducted by Anna (2001), Afruri (2009) and Aaron et al (2014). Directorate of Plant Protection Agency (2002) states that female beetles attacked the cherries from the age of 8 weeks after flowering to harvest.

The characteristics of the adult beetle is black with a front wing and a large pronotum and short spiked. The body length of approximately $2 \mathrm{~mm}(1.2 \mathrm{~mm}$ female; male $1.7 \mathrm{~mm})$. Larvae are white and actively foraging or menggerek fruit/coffee beans. Female beetles were more damaging because it makes the drill hole at the end of the coffee fruit skin is still green (discus) and turned into one of the seeds. Eggs are laid on the coffee fruit seeds have been hardened or on the fruit which has been cooked. Inside the coffee beans are cavity where the eggs laid. In one seed can be placed over an egg. Fecundity females reach 70 grain beetles are placed during the second period of egglaying. Figure 1 shows the $H$. hampei, a. larvae in the coffee fruit is still fresh; b. Newly hatched larvae will soon eat seeds and damaging part by broaching. In the period until the cocoon, made a rather wide hole auger which would later be occupied by the cocoon. Long life cycle depending on the altitude where coffee plants grow and favorable conditions to survive in the warehouse that is about 20-36 days. Inside the shed just to survive and can not multiply and die while being subjected to drying coffee beans were perfect.

Coffee berry borer, $H$. hampei is not only found in red coffee berries, but can also be detected in the coffee fruit is green toward red. When associated with the life cycle of $H$. hampei then the time it takes for the eggs to become pupae $\pm 15-35$ days while the coffee fruit changes from green to red color lasts for one month. If the eggs are laid on the dark green fruit, then turns into a pupa along with fruit ripening dark green to red. This is consistent with the statement Wiryadiputra (2007) that the incubation period of 5-9 days and long-range eggs larvae 10-26 days before imago. Coffee and Cocoa Research Center Indonesia (2006) states the pupa length stage of H. hampei between 4-9 days in the coffee plantations.

Stadia imago present in all ages of the coffee fruit. Attack of H.hampei have since young fruit until the fruit is old as Wiryadiputra statement (1996), $\mathrm{H}$. hampei pests since fruit during 2 months old, whose seeds are still in a state of soft, ripe fruit until the age of 4 months and a black cook, either still on the tree or who have fallen on the ground. Rubio et al. (2008) suggested that the imago H. hampei has ruined coffee beans from the coffee beans begin to form the endosperm. Female wasps lay eggs in the coffee fruit has had a hard endosperm. In the fruit that was attacked 
had more than one imago in one of the coffee fruit. This is due to start until the egg stage $H$. hampei imago insect remains in the seeds and broaching in the coffee beans. As stated by Kalshoven (1981) that the development from egg to imago takes place only in the hard seeds are ripe age of 3 months, supported by Irulandi et al. (2007) states that the coffee berry borer eat and breed only in the coffee beans.
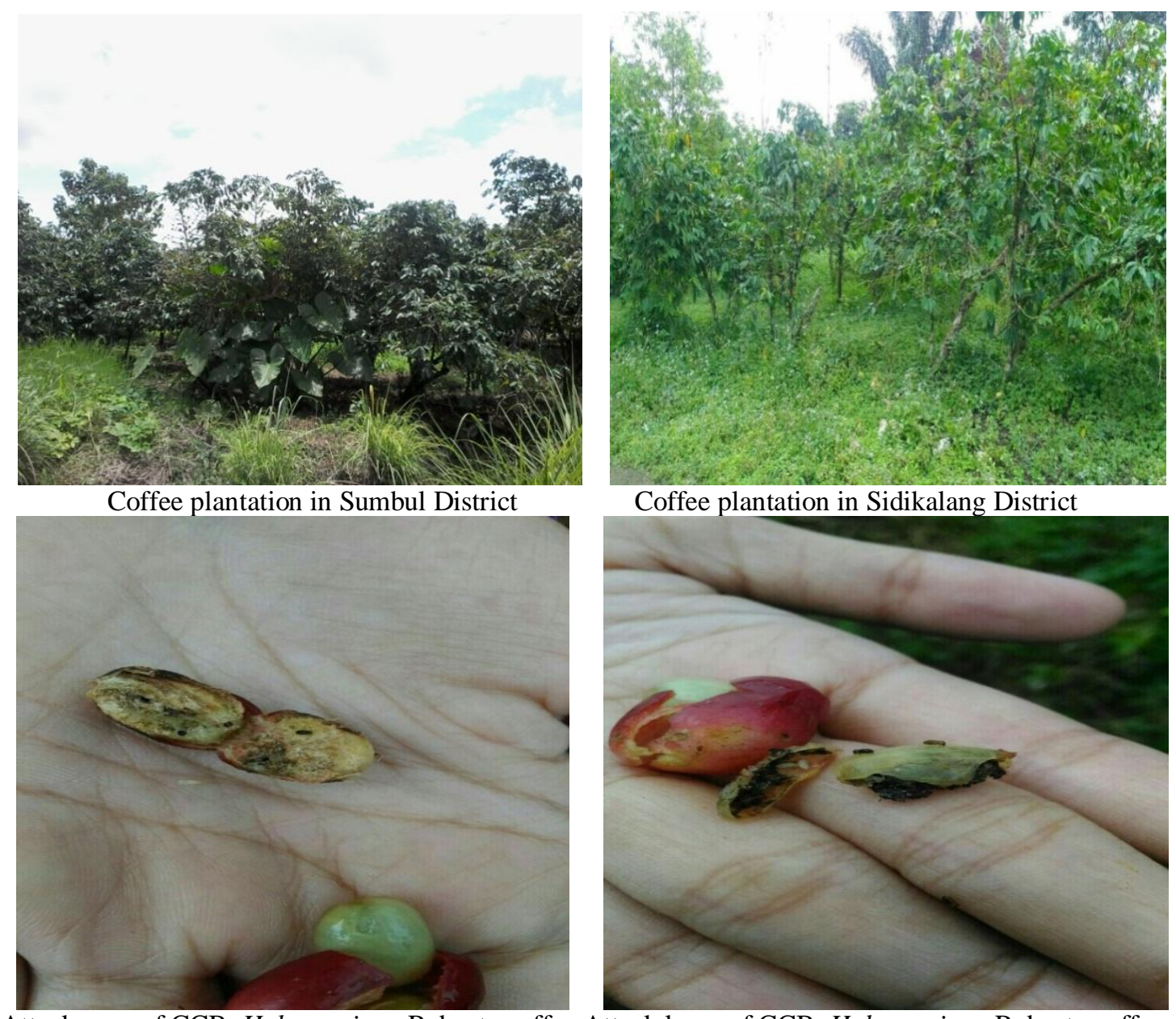

Attack eggs of CCB, H. hampei on Robusta coffee Attack larva of CCB, H. hampei on Robusta coffee
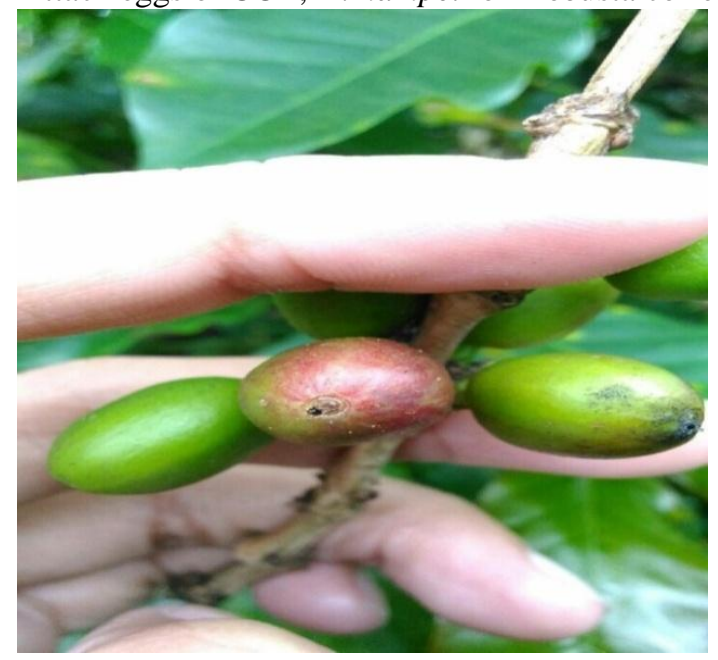

Atack of CBB, H hampei on Arabica coffee

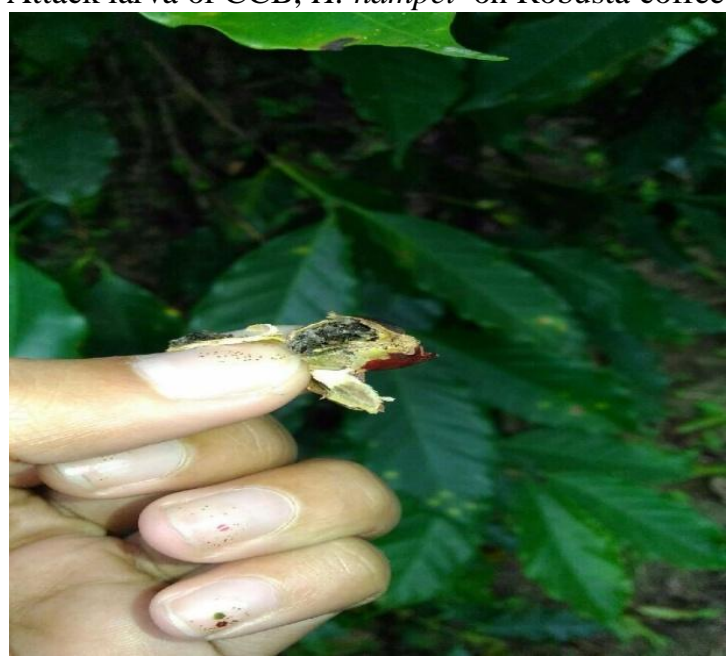

Figure 1:- Atack of CBB, H. hampei in Sumbul dan Sidikalang Districts, Dairi 
Total CBB trapped in the Bottle Contains Attractant of Chlorogenic Acid

Total PBKo trapped in the bottle trap can be seen in Table 1 below.

Table 1:- Number CBB trapped in the bottle attractant traps in Dairi

\begin{tabular}{|c|c|c|c|c|c|c|c|c|c|c|c|}
\hline $\begin{array}{l}\text { Zones-\% Atractan- } \\
\text { Type cofee- Treatment }\end{array}$ & S1 & S2 & S3 & S4 & S5 & S6 & S7 & S8 & S9 & S10 & Total \\
\hline SiK0A1S1 & 5 & 7 & 6 & 5 & 4 & 8 & 7 & 4 & 5 & 6 & 57 \\
\hline SiK1A2S1 & 4 & 6 & 5 & 10 & 7 & 12 & 10 & 7 & 8 & 6 & 75 \\
\hline SiK2A3S1 & 3 & 5 & 4 & 8 & 9 & 10 & 11 & 5 & 7 & 6 & 68 \\
\hline SiK3A4S1 & 3 & 4 & 5 & 2 & 6 & 3 & 4 & 3 & 2 & 4 & 36 \\
\hline SiK4A5S1 & 4 & 7 & 6 & 5 & 4 & 2 & 3 & 2 & 3 & 3 & 39 \\
\hline SiK0R1S1 & 4 & 6 & 5 & 3 & 4 & 7 & 8 & 4 & 5 & 6 & 52 \\
\hline SiK1R2S1 & 6 & 4 & 3 & 5 & 7 & 8 & 9 & 3 & 5 & 4 & 54 \\
\hline SiK2R3S1 & 7 & 6 & 12 & 10 & 8 & 6 & 7 & 4 & 6 & 3 & 69 \\
\hline SiK3R4S1 & 12 & 9 & 10 & 4 & 5 & 7 & 6 & 4 & 5 & 3 & 65 \\
\hline SiK4R5S1 & 6 & 3 & 5 & 8 & 7 & 4 & 5 & 3 & 2 & 2 & 45 \\
\hline SiK0A1S2 & 7 & 6 & 5 & 12 & 8 & 10 & 12 & 6 & 7 & 5 & 78 \\
\hline SiK1A2S2 & 5 & 6 & 8 & 3 & 4 & 7 & 8 & 6 & 5 & 4 & 56 \\
\hline SiK2A3S2 & 2 & 3 & 4 & 7 & 5 & 6 & 7 & 4 & 3 & 4 & 45 \\
\hline SiK3A4S2 & 6 & 5 & 7 & 4 & 5 & 3 & 4 & 5 & 6 & 4 & 49 \\
\hline SiK4A5S2 & 8 & 9 & 5 & 12 & 14 & 7 & 8 & 4 & 5 & 3 & 75 \\
\hline SiK0R1S2 & 3 & 7 & 6 & 5 & 4 & 3 & 5 & 4 & 3 & 5 & 45 \\
\hline SiK1R2S2 & 5 & 8 & 10 & 12 & 7 & 5 & 6 & 6 & 3 & 4 & 66 \\
\hline SiK2R3S2 & 9 & 14 & 10 & 12 & 6 & 8 & 7 & 5 & 6 & 4 & 81 \\
\hline SiK3R4S2 & 8 & 6 & 12 & 7 & 5 & 4 & 5 & 3 & 4 & 5 & 59 \\
\hline SiK4R5S2 & 10 & 7 & 4 & 6 & 10 & 5 & 6 & 4 & 3 & 5 & 60 \\
\hline SiK0A1S3 & 8 & 9 & 12 & 8 & 6 & 4 & 4 & 3 & 3 & 4 & 61 \\
\hline SiK1A2S3 & 7 & 5 & 8 & 7 & 6 & 5 & 6 & 5 & 4 & 3 & 56 \\
\hline SiK2A3S3 & 6 & 5 & 8 & 9 & 3 & 4 & 5 & 6 & 5 & 4 & 55 \\
\hline SiK3A4S3 & 5 & 7 & 8 & 12 & 10 & 9 & 10 & 7 & 6 & 5 & 79 \\
\hline SiK4A5S3 & 8 & 8 & 10 & 4 & 5 & 6 & 8 & 4 & 3 & 5 & 61 \\
\hline SiK0R1S3 & 6 & 10 & 2 & 5 & 3 & 12 & 14 & 6 & 5 & 4 & 67 \\
\hline SiK1R2S3 & 5 & 9 & 14 & 7 & 10 & 5 & 5 & 4 & 6 & 5 & 70 \\
\hline SiK2R3S3 & 8 & 4 & 10 & 5 & 3 & 7 & 5 & 4 & 5 & 4 & 55 \\
\hline SiK3R4S3 & 9 & 5 & 8 & 12 & 4 & 6 & 7 & 6 & 4 & 5 & 66 \\
\hline SiK4R5S3 & 7 & 8 & 8 & 4 & 7 & 10 & 12 & 8 & 6 & 7 & 77 \\
\hline SiK0A1S4 & 4 & 12 & 4 & 5 & 6 & 4 & 5 & 4 & 3 & 5 & 52 \\
\hline SiK1A2S4 & 3 & 3 & 6 & 5 & 7 & 3 & 4 & 3 & 4 & 2 & 40 \\
\hline SiK2A3S4 & 5 & 8 & 4 & 6 & 6 & 2 & 3 & 5 & 4 & 3 & 46 \\
\hline SiK3A4S4 & 8 & 3 & 5 & 7 & 10 & 3 & 2 & 3 & 5 & 4 & 50 \\
\hline SiK4A5S4 & 6 & 7 & 12 & 4 & 7 & 5 & 6 & 5 & 3 & 4 & 59 \\
\hline SiK0R1S4 & 7 & 6 & 5 & 3 & 10 & 6 & 7 & 6 & 5 & 3 & 58 \\
\hline SiK1R2S4 & 3 & 5 & 9 & 4 & 7 & 6 & 7 & 4 & 5 & 2 & 52 \\
\hline SiK2R3S4 & 6 & 8 & 7 & 4 & 3 & 5 & 6 & 3 & 4 & 4 & 50 \\
\hline SiK3R4S4 & 10 & 6 & 2 & 9 & 3 & 4 & 5 & 3 & 2 & 1 & 45 \\
\hline SiK4R5S4 & 5 & 7 & 3 & 6 & 4 & 2 & 4 & 3 & 2 & 1 & 37 \\
\hline SiK0A1S5 & 8 & 6 & 5 & 4 & 3 & 5 & 7 & 5 & 4 & 2 & 49 \\
\hline SiK1A2S5 & 4 & 6 & 5 & 10 & 7 & 2 & 4 & 3 & 2 & 4 & 47 \\
\hline SiK2A3S5 & 3 & 4 & 6 & 8 & 5 & 7 & 5 & 4 & 2 & 3 & 47 \\
\hline SiK3A4S5 & 12 & 6 & 4 & 9 & 7 & 8 & 7 & 6 & 5 & 3 & 67 \\
\hline SiK4A5S5 & 10 & 9 & 5 & 12 & 7 & 6 & 8 & 6 & 4 & 2 & 69 \\
\hline SiK0R1S5 & 5 & 7 & 6 & 8 & 9 & 10 & 9 & 7 & 6 & 3 & 70 \\
\hline SiK1R2S5 & 9 & 5 & 10 & 6 & 7 & 8 & 10 & 6 & 5 & 4 & 70 \\
\hline SiK2R3S5 & 10 & 3 & 7 & 8 & 5 & 4 & 5 & 3 & 2 & 3 & 50 \\
\hline
\end{tabular}




\begin{tabular}{|c|c|c|c|c|c|c|c|c|c|c|c|}
\hline SiK3R4S5 & 4 & 12 & 8 & 3 & 6 & 7 & 8 & 6 & 5 & 4 & 63 \\
\hline SiK4R5S5 & 7 & 4 & 2 & 6 & 9 & 5 & 6 & 2 & 3 & 4 & 48 \\
\hline SuK0A1S1 & 12 & 6 & 6 & 10 & 5 & 3 & 4 & 3 & 1 & 3 & 53 \\
\hline SuK1A2S1 & 7 & 3 & 9 & 8 & 4 & 3 & 5 & 2 & 3 & 4 & 48 \\
\hline SuK2A3S1 & 6 & 2 & 5 & 6 & 8 & 4 & 6 & 5 & 2 & 3 & 47 \\
\hline SuK3A4S1 & 7 & 10 & 2 & 5 & 4 & 3 & 5 & 4 & 0 & 3 & 43 \\
\hline SuK4A5S1 & 8 & 7 & 9 & 2 & 3 & 5 & 7 & 5 & 4 & 3 & 53 \\
\hline SuK0R1S1 & 4 & 3 & 8 & 7 & 6 & 12 & 10 & 6 & 5 & 2 & 63 \\
\hline SuK1R2S1 & 8 & 4 & 5 & 7 & 3 & 2 & 4 & 3 & 1 & 2 & 39 \\
\hline SuK2R3S1 & 6 & 7 & 2 & 5 & 4 & 5 & 3 & 1 & 2 & 3 & 38 \\
\hline SuK3R4S1 & 10 & 5 & 8 & 12 & 8 & 7 & 6 & 5 & 3 & 4 & 68 \\
\hline SuK4R5S1 & 10 & 7 & 6 & 4 & 8 & 5 & 6 & 3 & 4 & 2 & 55 \\
\hline SuK0A1S2 & 9 & 1 & 10 & 4 & 7 & 5 & 4 & 2 & 2 & 1 & 45 \\
\hline SuK1A2S2 & 3 & 4 & 4 & 2 & 3 & 3 & 5 & 4 & 3 & 2 & 33 \\
\hline SuK2A3S2 & 2 & 2 & 6 & 5 & 2 & 4 & 6 & 5 & 4 & 3 & 39 \\
\hline SuK3A4S2 & 9 & 3 & 5 & 2 & 7 & 4 & 5 & 4 & 3 & 2 & 44 \\
\hline SuK4A5S2 & 1 & 9 & 6 & 3 & 7 & 5 & 7 & 5 & 4 & 3 & 50 \\
\hline SuK0R1S2 & 2 & 7 & 3 & 4 & 5 & 2 & 4 & 2 & 3 & 1 & 33 \\
\hline SuK1R2S2 & 10 & 7 & 3 & 5 & 8 & 4 & 5 & 4 & 2 & 1 & 49 \\
\hline SuK2R3S2 & 1 & 5 & 2 & 4 & 3 & 6 & 7 & 5 & 3 & 4 & 40 \\
\hline SuK3R4S2 & 4 & 5 & 6 & 7 & 4 & 3 & 4 & 4 & 3 & 1 & 41 \\
\hline SuK4R5S2 & 9 & 2 & 7 & 5 & 4 & 8 & 10 & 6 & 5 & 4 & 60 \\
\hline SuK0A1S3 & 1 & 8 & 6 & 3 & 6 & 2 & 3 & 2 & 1 & 0 & 32 \\
\hline SuK1A2S3 & 4 & 3 & 5 & 7 & 6 & 3 & 4 & 3 & 1 & 2 & 38 \\
\hline SuK2A3S3 & 6 & 5 & 2 & 3 & 4 & 8 & 9 & 8 & 5 & 4 & 54 \\
\hline SuK3A4S3 & 5 & 7 & 3 & 4 & 5 & 8 & 10 & 6 & 4 & 3 & 55 \\
\hline SuK4A5S3 & 8 & 3 & 6 & 4 & 2 & 5 & 6 & 3 & 5 & 2 & 44 \\
\hline SuK0R1S3 & 7 & 5 & 2 & 6 & 3 & 1 & 3 & 1 & 2 & 2 & 32 \\
\hline SuK1R2S3 & 5 & 6 & 4 & 7 & 3 & 2 & 4 & 3 & 1 & 3 & 38 \\
\hline SuK2R3S3 & 8 & 7 & 6 & 5 & 3 & 4 & 6 & 4 & 2 & 5 & 50 \\
\hline SuK3R4S3 & 7 & 6 & 2 & 5 & 4 & 2 & 5 & 3 & 2 & 1 & 37 \\
\hline SuK4R5S3 & 10 & 3 & 7 & 5 & 12 & 3 & 4 & 4 & 3 & 1 & 52 \\
\hline SuK0A1S4 & 4 & 10 & 6 & 5 & 9 & 4 & 5 & 3 & 2 & 0 & 48 \\
\hline SuK1A2S4 & 3 & 5 & 6 & 8 & 7 & 1 & 3 & 1 & 0 & 2 & 36 \\
\hline SuK2A3S4 & 12 & 4 & 6 & 2 & 3 & 2 & 4 & 1 & 2 & 1 & 37 \\
\hline SuK3A4S4 & 7 & 8 & 5 & 6 & 4 & 1 & 3 & 1 & 1 & 1 & 37 \\
\hline SuK4A5S4 & 6 & 2 & 7 & 8 & 3 & 4 & 5 & 2 & 1 & 1 & 39 \\
\hline SuK0R1S4 & 2 & 5 & 1 & 2 & 3 & 3 & 4 & 2 & 1 & 0 & 23 \\
\hline SuK1R2S4 & 4 & 1 & 3 & 5 & 2 & 6 & 7 & 3 & 2 & 1 & 34 \\
\hline SuK2R3S4 & 5 & 6 & 4 & 1 & 3 & 2 & 4 & 3 & 2 & 0 & 30 \\
\hline SuK3R4S4 & 5 & 9 & 3 & 7 & 6 & 4 & 5 & 4 & 1 & 0 & 44 \\
\hline SuK4R5S4 & 5 & 4 & 7 & 3 & 6 & 8 & 9 & 5 & 3 & 2 & 52 \\
\hline SuK0A1S5 & 5 & 2 & 3 & 7 & 4 & 8 & 10 & 6 & 2 & 3 & 50 \\
\hline SuK1A2S5 & 7 & 12 & 5 & 4 & 6 & 2 & 4 & 1 & 2 & 1 & 44 \\
\hline SuK2A3S5 & 7 & 5 & 6 & 8 & 4 & 3 & 5 & 2 & 1 & 1 & 42 \\
\hline SuK3A4S5 & 6 & 8 & 3 & 5 & 4 & 10 & 12 & 6 & 5 & 4 & 63 \\
\hline SuK4A5S5 & 2 & 3 & 5 & 4 & 8 & 7 & 8 & 3 & 4 & 5 & 49 \\
\hline SuK0R1S5 & 7 & 1 & 5 & 6 & 3 & 6 & 7 & 5 & 4 & 6 & 50 \\
\hline SuK1R2S5 & 7 & 4 & 8 & 2 & 7 & 3 & 5 & 3 & 1 & 1 & 41 \\
\hline SuK2R3S5 & 3 & 4 & 5 & 7 & 6 & 2 & 4 & 2 & 1 & 1 & 35 \\
\hline SuK3R4S5 & 2 & 12 & 4 & 8 & 7 & 10 & 12 & 6 & 4 & 2 & 67 \\
\hline SuK4R5S5 & 4 & 10 & 5 & 6 & 8 & 6 & 8 & 3 & 2 & 2 & 54 \\
\hline
\end{tabular}


Catatan: $\mathrm{Si}=$ Sidikalang, $\mathrm{Su}=$ Sumbul; $\mathrm{K} 0=\mathrm{Kontrol}, \mathrm{K} 1=$ extract of chlorogenic+water $25 \mathrm{ml}$, K2=extract of chlorogenic+water $50 \mathrm{ml}, \mathrm{K} 3=$ extract of chlorogenic+water $75 \mathrm{ml}, \mathrm{K} 4=$ extract of chlorogenic+water $100 \mathrm{ml}$; $\mathrm{A}=$ Arabika, $\mathrm{R}=$ Robusta; $\mathrm{S}=$ Replicates.

Attractant trap of chlorogenic acid from leaves and bark of the coffee fruit is most effective in controlling the pest PBKo in the field of ten repetitions found seven replicates significantly to repeat with each value of $p<0.02$ on third replicates (S3) and the tenth replicates (S10), while the very real differences recorded in the fourth replicates (S4), the sixth replicates (S6), the seventh replicates (S7), the eighth replicates (S8), and ninth replicates (S9). According to Clifford (1999); CIRAD (2004); Damon (2001); Feny and Endang (2014) that the use of attractant uch as methyl eugenol, traps colors, especially blue or red can control PBKo attack of the coffee plant. Integrated Pest Management and the use of pheromones performed by Laila et al. (2011); Ceylon (2012) and Nugroho (2015).

\section{Conclusions And Recommendations:-}

Coffee is a beverage connoisseur economical for the people of North Sumatra. The Dairi coffee producing centers have major problems detected dominant pest H.hampei, CBB. The results showed Bio-ecology of $H$. hampei pests that can be observed from the development of the egg, pupa and imago of H.hampei in Sumbul and Sidikalang, Dairi. Attractant trap chlorogenic acid from leaves and bark of the coffee fruit is most effective in controlling the pest of CBB in the field of ten repetitions recorded 7 replicates very significant, consisting of the S3, S4, S6, S7, S8, S9 and S10 (values: p <0:00-0.02). Developments $H$. hampei affected by temperature and the availability of the coffee fruit. Factors influencing the development of $H$. hampei namely; continuous supply of fruit from generation to generation; the shade is too dense resulting in high humidity; and fulfilled the host plant consisting of Tephrosia sp, sp Centrosoma, Oxicanthus sp. the use of attractants chlorogenic acid leaves and rind of coffee pest control of CBB (H.hampei) is one effort in keeping the coffee commodity Dairi, North Sumatra.

\section{Acknowledgements:-}

The author would like to thank the coffee farmers and communities in Sumbul and Sidikalang Districts, Dairi and Agroecotechnology Department, Faculty of Agriculture, USU. Thanks to the Research Institute of the University Sumatera Utara, the Ministry of Research and Technology, the Directorate General of Higher Education of the Republic of Indonesia to grant BP-PTN 2016.

\section{Refferences:-}

1. Aaron B. N., Darma Bakti and Marheni. 2015. Insect species diversity in cropping Coffea arabica L. After volcanic ash eruption of Mount Sinabung in Karo. Journal Agroecotechnology 4 (1): 1726-1734.

2. Afruri. 2009. Important Coffee Plant Pests. http://afruri.blogspot.com/2009/06/dominance-pests-coffeeplantation. html. Accessed on May 9, 2014.

3. Anggraini, S., and Fredy, K. 2015. Effects of Difusion Time in Levels of Chlorogenic Acid in Sample Black Tea and Green Tea. Institute of Technology (ITS). Surabaya.

4. Anne Damon. 2001. A review of the biology control of the coffee berry borer, H.hampei (Coleoptera: Scolytidae). Bulletin of Entomological Research. January 2001.pp. 452-465.

5. Clifford, M.N. 1999 Review: Chlorogenic acids and other Cinnamates nature, occurrence and dietary burden. Journal of the Science of Food and Agriculture. 79: 362-372.

6. Embriani. 2014. AlternativeCchlorogenic Acid Attractant of Cacao Fruit Borer. BBPPTP. Surabaya.

7. Feny Ernawati and Endang Hidayanti. 2014. Development of the Coffee Plant Pests of CBB. POPT First, Surabaya.

8. Firmansyah AP. Sjam S. and Goddess VS, 2013. Coffee Bean Extract for Attractant Imago of Cocoa Fruit Borer (C. cramerella). UNHAS. Makassar.

9. Herath, A. and Asep, S. 2013. Effects of Chlorogenic Acid Lampung Robusta Coffee Against Expression of Cyclin D1 and Caspase 3 In Cell Lines HEP-G2. Research Institute of the University of Lampung. Lampung.

10. Khairati, N. 2012. Influence Sales Arabica Coffee In The Form Of Fruit Harvest (Cherry Red) Against Economic Arabica Coffee Growers Tanjung Beringin In Dairi. USU. Field.

11. Krebs. 1978. Ecology. The Experimental Analysis of Distribution and abundance. Third Edition. Harper and Row Publishers.

12. Laila, M. S. I, Nurariaty, A., and Annie, P. S. 2011. Applications for the concept of Integrated Pest Management pest control coffee berry borer powders (H. hampei). J. Fitomedika. 7 (3): 162-166 (2011).

13. Malau, S. 2010. Attacks Coffee Berry Borer and Its Impact on Samosir. Report USU. 
14. Malau, S., P. LB King, B. Naibaho, S. T. T. Sumihar, and R. Simanjuntak. 2012. Study On The Effect Of PlantBased Natural attractant Local and Pest Trapping Made for Coffee Berry Borer in North Sumatra. Research and Development of North Sumatra Province. Field Guideline Book.

15. Moralla-Rejesus, B., 1986. Botanical Insecticides Against Diamondback Moth. Proc. of the First Int. Workshop.

16. Murphy, S.T. \& Moore, D. 1990. Biological Control of the Coffee Berry Borer, Hypothenemus hampei, (Ferrari) (Coleoptera: Scolytida): Previous Programmes and Possibilities for the Future. Biocontrol News and Information $11,107-117$.

17. Nugroho, A. 2015 B. Control of Coffee Fruit Borer (H. hampei) On Coffee Plant Using Pheromones. BBPPTP. Surabaya.

18. Protection Field. I. 2014. Quarterly Data Protection Field seeding and gGeat Hall Crops Protection Surabaya, Jombang.

19. Riyanto. 2007. The density, distribution patterns and ant role in plants around the residential area. Sciences Research Journal 2 (10): 241-253.

20. Renwick, J.A.A \& F.S. Chew. 1994. Oviposition Behavior In Lepidoptera. Annu. Rev. Entornot. 1994. 39: 377 400.

21. Ceylon. 2012. Pest Control Coffee Fruit Powders (Hyphotenemus hampei Ferr). KJF BP4K Central Bengkulu district and Trustees P4S Cita Laksana Mandiri. http://kjfbenteng.blogspot.com/2012/12/powderpest-fruitcofee.html. Accessed September 2, 2016.

22. Sartika. 2012. Coffee Plant Pests and Diseases. Essay. Brawijaya University. Poor.

23. Source Data protection field BBPPTP Surabaya. I. Quarter 2014 Data Source Data protection field Great Hall Plantation Seed and Plant Protection Surabaya, Jombang.

24. Siregar, A. Z. 2016. Types of Coffee Plant and Pest Underlying. USU. Field.

25. Situmorang T S. 2013. Debt Sigarar coffee from northern Sumatra. Section Plantation Seed and Plant Protection (BBPPTP). Field Book. 